\title{
The Role of Financial Sector on Economic Growth: Theoretical and Empirical Literature Reviews Analysis
}

Hamad Omar Bakar ${ }^{*}$ and Zunaidah Sulong

Faculty of Economics and Management Sciences, Universiti Sultan Zainal Abidin, Gong Badak Campus, Kuala Terengganu, Terengganu, Malaysia

"Corresponding author: Hamad Omar Bakar, Faculty of Economics and Management Sciences, Universiti Sultan Zainal Abidin (UniSZA), Gong Badak Campus, Kuala Terengganu, Terengganu, Malaysia, Tel: +09-668-8231; E-mail: hamadsmall@yahoo.com

Received Date: Sep 10, 2018; Accepted Date: Oct 09, 2018; Published Date: Oct 19, 2018

Copyright: @ 2018 Bakar HO, et al. This is an open-access article distributed under the terms of the Creative Commons Attribution License, which permits unrestricted use, distribution, and reproduction in any medium, provided the original author and source are credited.

\section{Abstract}

This article reviews literatures on effect of financial development on economic growth. The samples of literatures from different time frames were taken into consideration to ensure the mixture of ideas and results. The results, implications and discussion were presented at each category. It seems that, the effect of financial development on economic growth is subject to selection of time frames selected, sample of countries, list of variables and proxy. However, in most cases it seems that the impact of financial sector is more significant and positive to the developing countries compared to developed countries. Given the recently development of methodologies in terms of econometrics methods and use of proxy such as Financial index, it is important to apply in the future research. This will help to determine the effect of financial sector on economic growth in more advanced way, rather than relies on past proxy and methodologies.
\end{abstract}

Keywords: Financial; Productivity; Macroeconomic; Development

\section{Introduction}

Financial sector attracts deposits and provide loans from surplus to deficit side. The overall impact of financial sector in economy is to ensure sustainable growth. It helps to mobilize savings and direct funds into production sectors. As results, it facilitates efficient allocation of resources and increases overall productivity. It also facilitates delivery of products and services, management of risks, easier payments. In addition, it ensures the availability of different instruments, such as insurance packages, and information that facilitates trade activities. Financial development promotes growth via increasing capital accumulation efficiency together and improving marginal productivity consequential from it ${ }^{1}$. Despite the fact that, conventional idea is financial sector promotes economic growth, but the empirical literatures have no consensus to date.

This article described the discussions from the quantity of literatures into four categories so that to capture the discussions on the different results provided from the different researches. The samples of literatures from different time frames were taken into consideration to ensure the mixture of ideas and results. The paper categories the discussions into four main sections, first and second sections described by considering the effect of financial sector whether it is positive or negative. Third part explains the effect of financial sector to higher income and lower income countries. The Fourth part explains the transmission channels of financial sector on economic growth. Further subsections to each part are explained within the articles.

\section{Effect of Financial Development on Economic Growth is Positive}

The effect of financial sector has said to be positive which implies that financial sector promotes and is more significant on economic growth. These article has been categorized for the into two subsections, which conducted to the groups of countries (Panel and Cross Sectional) and Individual countries (Panel and Time Series).

\section{Sample of groups of countries (panel and cross sectional studies)}

Generally, it is argued that most of the studies focused on cross section and panel data support the view that, finance influence growth even after take into account growth covariates, biases, omitted variables as well as unobserved country specific effect $[1,2]$

Levine et al and Al-Yousif using panel GMM techniques and traditional cross sections for 71 countries claimed that, financial development indicators are highly positive and significant relation on economic growth $[3,4]$. Apergis et al. also confirmed positive relation between finance and growth for both developing and developed regions [5]. Kar et al. concluded that in Mena countries financial development is a source of growth rate in a period (1980-2007) [6].

Moreover, studied a panel of 16 MENA countries via GMM (2005-2014), concluded that both proxies used, confirm positive relation on growth in pre-Arab spring while on other hand some of the macroeconomic indicators improved but others exacerbated. In addition to that, Omri et al. via GMM approach for 12 MENA countries (1990-2011) found that, credit to private sector has positive relation and unidirectional causality which run from finance to growth [7]. The finding gives clear insight that the higher financial

1 This assumption is consistent with the theoretical earlier work by (Goldsmith 1969). Moreover, finance spur growth through the increase of the savings rate has demonstrated by (McKinnon 1973; Shaw 1973). 
development promotes economic growth. Abubakar et al. using cointegration, FMOLS and DOLS (1980-2011) confirmed that private credit and credit by bank spur growth in ECOWAS region [8]. The influence of these indicator to generate growth also via human capital accumulation.

Moreover, Muhammad et al. via GMM for GCC region (1975-2012) after critical analysis concludes a positive relation finance to output growth in GCC countries [9]. Similar results supported by authors via ARDL and Ibrahim through a FMOLS for Saudi Arabian economy used GMM technique found positive ratio of quasi money effect of to economic.

Similarly, Masoud and Hardaker confirmed that stock market and banking sector boost output growth for 42 emerging market countries [10]. Ibrahim et al. employ banking sector and stock market in 53 countries, indicated that, both indicators are the engine toward boosting economic growth in these countries during the study period. Likewise, Van claimed that stock market provides long term capital to the firms which are very important for growth. Using similar proxies, Beck and Levine confirmed that financial development has a large impact on growth [11]. In their overall finding illustrated that an increase of financial development measures leads to stimulate the growth rate of these countries. They suggested that, both domestic credit and bond markets play a significant role in growth.

In 65 developing countries agreed that financial sector is very crucial in growth enhance in the sample countries. Furthermore, Hsueh et al. through economic growth model, adopted bootstrap approach granger causality analysis (1980-2007) in OECD countries founded that, domestic claims, M1, M2 and M3 is very important in generating growth since has shown a positive effect [12]. Further the results found the presence of causality between financial development and growth. Also, Estrada et al. after analytical investigation on a panel of 125 countries confirm financial development measures accelerate growth rate for the selected countries [13]. Author studied 16 European Countries (1988-2012) confirmed that, finance promotes growth.

In addition to that, Pradhan et al. claimed that both individual indicator and composite index demonstrated a vigorous positive relation with economic growth for 22 Arab league counties (2001-2013) [14]. Similarly, Authors recognized positive relation of financial development index to growth for South-Asian association for regional cooperation (SAARC) during (1994-2013). Pradhan et al revealed that financial development spur economic growth for both developed and developing countries [14]. At the same time the study confirms the existence of causality which path from financial development to growth. Ciftci et al (2016) found that credit and stock market have along run contribution of growth on a panel of 40 countries (1989-2011). The finding also is in line with earlier investigation by Levine and Zervos, Beck et al. $[15,16]$. However, the more effect observed via credit market compared to stock market development.

A recent study by author for the EU members examined weather banking sector is affected by financial crisis. The results indicated that several financial ratios (banking sector) has a positive significant relation in generating growth in EU countries. Their results were not robust on before and after financial crisis. Via recent approach of Nonlinear Autoregressive Distributed Lags (NARDL) found that, the stage of economic development matter for financial structure. These finding are in line with previous evidence, who argued that the structure of the financial system is important for the economic development.

Likewise, a recent study by Assefa and Mollic for 15 African countries in a period 1995-2010 also confirms the positive significant relation between finance and economic growth [17]. Author reveals that financial development as measured by credit market and stock market is an engine for generating growth output for the majority of the countries studied since observed positive sign in long run effects. This finding is associated with earlier study by Levine and Zervos [15].

In addition to that, Research 16 South-Eastern and Central European countries reveled that there is a long run relation of finance to growth effect and highly robust to alternative panel co integration technique. Enowbi et al. for 41 African countries, economic growth decrease financial instability while the higher degree of reduction exists at the pre-liberalization rather than post liberalization [18].

Sample of individual countries (panel and time series): In contrast to cross country studies, there are ample of literatures conducted on individual countries, where specific measures of financial development with respect to individual countries are developed, as results it avoids dealing with country specific factor in regression analysis. Also, most of these studies support the notation that, financial development plays a significant role in enhancing economic growth.

Author indicated that, financial development spur firm growth in Italy, which further boost the probability of an individual on starting their own business. Zhang et al through GMM technique concluded that, city level benefited from the financial development after observed positive association with growth [19]. The finding recommends the necessity of financial reforms initiated after China's accession to the WTO. This finding is consistent with the earlier studies that employ similar measure of city level [20]. Adu et al. through ARDL model (1961-2010) demonstrated that, credit to private sector and total domestic credit are favorable for growth in Ghana. However, the study illustrated that selected measures (indicators) is sensitive to determine the effect of financial development [21].

Further study by Uddin et al. employed ARDL approach and an index of financial development is good for growth rate in Kenya [22]. The result is in line with previous finding observed by Ang and Mckibbin for Malaysia; Khan and Qayyum, and Shahbaz for Pakistan and Kar et al. for Turkey. Moreover, through ARDL model in Tunisia suggested that, among three indicators of financial sector only credit to private sector driven growth outcome in Tunisia for a long term [23-27]. Other indicators stock market development and bank intervention in stock market failed to show robust and significant positive relation on growth both short and long run.

Also, earlier work by Ghali via Vector auto regression (VAR) in Tunisia (1963-1993) demonstrated the strong long run effect between fiancé and growth in Tunisia [28]. Badeeb and Lean explained that, the selected proxy which represents financial development play a positive role in influencing the growth rate in Republic of Yemen (1990-2012) [29]. Likewise, in Bahrain, Altaee and Al-Jafari claimed that, ratio of domestic credit has positive impact to economic growth. In addition to that, Badeeb and Lean used ARDL approach and found that, domestic credit to private sector has positive effect to economic growth in Yemen $[29,30]$. Similarly, Sbia and Alrousan via ARDL model found that credit to private sector is important in generating growth in UAE (1975-2012) [31]. 
Page 3 of 6

Zarrouk et al. also claimed that, financial development as measured by composite indicator seems to have a significant role in enhancing growth [32]. In line with causality pattern, the result confirms that the existing causal running from finance to growth only. In addition to that, Author suggested that, credit to private sector which is the only indicator for financial development utilized a positive and significant effect on growth in Kenya both short and long run periods using ARDL technique (1960-2014) concluded that, finance is a good mechanism in raising economic growth in India.

\section{Effect of financial development on economic growth is negative}

Many literatures both in cross section and individual countries also reported that, there is negative effect of financial sector on economic growth due to either financial crisis during the research period, low development of financial sector and below threshold point, lacking of efficient resource allocation by banks together with absence of conducive environment for favorable investment at the private sector are main factors for their negative. For example, Koivu suggested negative effect of private credit to private sector on 25 transition economy (1993-2000) [33]. Similarly, Gillman and Harris (2004) for 13 transition countries, found negative and significant relation of Money supply (M2) on growth.

Authors revealed the negative effect of ration of M2 on growth of UAE. Moreover, Ram studied 95 individual countries where UAE included [34]. The finding besides establishes a negligible or weak negative effect and insignificant relation between financial development and growth. Similarly, using time series data (1974-2008) in UAE used ratio of money supply (M2) and private credit by commercial bank as proxy, established negative effect to economic growth [35].

Bolbol et al. indicated that, bank-based demonstrated has negative effect on total factor productivities in Egypt for period 1974-2002 [36]. Jalil and Ma established that, deposit liability ratio and private credit deteriorates economic growth in China, may be due to lacking of efficient resource allocation by banks together with absence of conducive environment for favorable investment at the private sector [37]. Similarly, Aziz and Duenwald found insignificant relation between total bank lending and economic growth in China [38].

Demetriades and James used sample of 18 SSA countries for a period 1975-2006 [39]. They study used multiple variable as an instrument to measure financial development including bank deposit, liquid liability and credit by bank (share to GDP). The result found no relation between financial development and growth in SSA countries. The finding of this study is in line with previous paper by Demetriades and Fielding and Andrianova et al. [40,41].

Ayadi et al. using GMM estimator (1985-2009) for the Mediterranean countries (Southern and Northern) suggested that, both credit to the private sector and bank deposits associated negative effect on generating economic growth [42]. Adu et al found that broad money stock has negative effect to the economy of Ghana [21]. Authors examined Middle Eastern countries. They conclude negative impact of financial sector on the economy with the exception of Asia region. Barajas et al. found lower and even negative impact of financial sector on growth in oil rich and MENA countries [43]. Low development of financial sector and below threshold point may be the reasons.
Sassi and Goaied applied GMM advance technique to analyze the same link for 17 MENA region countries over a period 1960-2009 [44]. Using the overall index of financial sector confirmed negative relation between financial development and growth. Furthermore, Menyah et al. suggested that financial development doesn't seem to have made significant impact on growth on African Countries [45]. Moreover, observed that credit to private sector and interest margin negatively associated with economic growth for a total of 16 transition economy from Central and South Eastern Europe.

Moreover, in 10 Central and Eastern Europe (1999-2006) concluded that bad loan is harmful for growth. Similar conclusion for M3 though somehow is not as strong as bad loan but still have negative effect. Samargandi et al using several proxies such as broad money (M2), ratio of liquid liabilities (M3) and the ratio of credit to private sector found negative though insignificant impact to the growth [46]. Also, 1980-2010. Adeniyi et al employing ARDL approach indicated a negative impact of ratio of liquid liability, credit to private sector and the ratio of M3 on economic growth in Nigeria for a period [47].

\section{Effect of Financial Development by Income Groups}

The existing evidence also demonstrates that, the relation between finance and growth varies due to the level of income in some certain countries. It is explained that, financial development is more significant and benefited in developing economy countries. They suggested that, in developed countries overall volume of financial development is operated outside the banking sector which result slight effect compared to middle and low income countries where financial system still dominated by banking sector.

\section{According to the level of income}

Moreover, the existing evidence also demonstrates that this relation between finance and growth varies due to the level of income in some certain countries. It is explained that, financial development is more significant and benefit in developing economy countries. However, this assumption also is debatable due to mixed result found in the literature. Despite this mixed result never the less many study exhibited that less developing countries profited more on financial development compared with developed economies.

Effect to lower income level countries: De Gregorio and Guidotti demonstrated a positive effect of financial development is more potential to the middle income countries together with low income countries than developed economy countries [48]. They suggested that, in developed countries overall volume of financial development is operated outside the banking sector which result slight effect compared to middle and low income countries where financial system still dominated by banking sector. However, Graff (1999) selected 93 countries for a period 1970 to 1990 to measure the finance -growth effect. Using constructed index grounded on ratio of employed workers and number of bank branches, suggested a stronger positive relation to developing countries than well-developed ones.

Authors demonstrated that structure of banking sector spur economic growth with more rapid increase in transition economy of Central and Eastern Europe compared with developed economy of OECD countries. Moreover, Calderon and Liu used Private credit and broad money (M2) in both industrial and developing countries and suggested that finance generate growth [20]. However, this positive relation economically influenced more in developing countries rather than developed countries. Also, Beck et al. in panel of 52 developing 
and developed regions suggested that, private credit had more significant effect to the income level of the poor and reduce inequality gap to developing countries compared to developed one due to well financial intermediation, that faster decline poverty and income inequality gap [11].

In addition to that, Huang and Lin, also exhibited the positive effect of financial development is much more significant in low income and middle income than in high income countries after applying Caner and Hansen 2004 threshold regression for a cross section data in 71 countries for a period 1960-1995 [49]. The Huang and Lee had similar to the finding demonstrated by Masten et al. who studied a sample of European countries [50]. They concluded that less developed countries benefited more from financial development compared with developed economy.

Effect to higher income level countries: In contrary to the previous studies, some of the studies demonstrated that high income countries benefited more from financial development rather than less developing countries. Their results based on the view that, developed countries have a sufficient and strong equity structure of financial system. Rioja and Valev mixed 74 developed and developing countries in a period 1961-1995 [51]. The finding reported a robust positive relation in middle income countries but weekly significant in poor countries.

Furthermore, Bangake and Eggoh examined a dynamic panel of 71 countries in a period 1960-2014 [52]. The result found that, there is a strong positive relation between financial development and growth in these countries. They asserted that no evidence found on short run effect for both low and middle income economy countries but for high income countries there was a strong considerable effect. Also, Herwartz and Walle examine financial development on growth in difference groups of 73 cross countries economy [53]. Using deposit money banks and other financial institutions to the non-financial private sector, the result confirmed that all measures of financial development reveal positive significant on growth.

However, this positive effect is very stronger in high- income than low- income economies. Owen and Temesvary find that the growth effect caused by various types of banking loaning is highly depends on the extent to which a certain country is well developed their banking sector [54]. This implies that the higher banking sector is, the higher output production exists.

\section{The Transmission Channels of Financial Development and Economic Growth}

Most of the literature in the 1980s and 1990s examined the effect of financial development either directly or indirectly ignoring the process of transmission channels. Nevertheless, recent empirical studied the financial development growth enhancing channels. For example, author classifies slow-moving institutions (culture, beliefs, and social norms) tend to change gradually and fast-moving institutions (political institutions) do not necessarily change often but can change quickly. The interaction between these two institutions can shed light on institutional change and hence economic growth and development.

\section{The interaction between financial sector and its channels to influence growth are positive}

Omran and Bolbol examined the interactive role of financial sector development such as bank-based and equity market indicators (19751999) in Arab countries [55]. Using OLS technique, concluded that interaction term of foreign direct investment and indictors of financial development affecting economic growth positively. Though this effect tends to exist only at a given threshold level of financial sector development in host Arab inclusive of the GCC countries. In 72 countries for the period 1978-2000 claimed that, financial development is most potent in middle-income countries, where its effect is particularly large when institutional quality is high.

In low-income countries, more financial development without sound institutions may not succeed in delivering long-run economic development. Also, in 35 cross countries (1992-2003) using GMM approach suggested that, both financial sector size and efficiency is a good mediator in generating growth. This is due to higher efficiency of financial sector enhances the use of productive financial capital which results in generating high growth. Likewise, the more and wellfunctioning financial sector have an ability to spend financial capital in efficiency way.

On top of that, Madsen and Ang examines the extent to which financial development transmits to growth through ideas production, savings, investment, and schooling using a unique new panel data set for 21 OECD countries (1870-2009) [23,56]. The empirical results show that, financial development influences growth through all channels. Specifically, ideas production is found to be the most important channel through which financial development impacts on growth. Masoud and Hardaker in 42 emerging market countries (1995-2006) suggested that, the interaction between bank asset ratios, market capitalization ratio and per capita is positive and significant relation [10].

Abubakar et al. using cointegration, FMOLS and DOLS (1980-2011) confirmed that private credit and credit by bank spur growth in ECOWAS region but through human capital accumulation [8]. This result provide insight that, the policy to influence human capital may contribute heavily on the importance of financial sector. For example, a study conducted by Law in the panel of 87 countries for period 1984-2014 indicated that, institutions play a positive role in mediating effect between banking sector development and growth.

In the authors study via GMM in 16 MENA observed that higher level of democratic rule in this region play a significant role in generating the output growth. This confirm the previous studies of Hearn who argued as more democratic rule exist the higher contribution of growth output increased from financial development [57]. Although this conclusion is rejected with Asongu [58].

\section{The interaction between financial sector and its transmission to influence growth is negative}

Though the previous studies have highlighted on the role of transmission factors to financial sector, but it happens otherwise to some few studies. However, this may be due to inefficiency of financial sector and low penetration level to remote areas especially in developing region. Muhammad et al who examined the GCC countries (1975-2012) via GMM suggested that foreign direct investment (FDI) had negative moderating effect on growth despite its interaction with financial sector, although when stand solely is good for growth [9]. Inadequacy of financial development that could attract more foreign direct investment was major reason. For example, Albiman and Zunaidah despite of using different proxy of financial sector, suggested on the negative interaction effect between ICT and financial development in SSA region [59]. Low penetration and inefficiency of financial sector within SSA region were major reasons. Similar results 
and conclusion were suggested in Asian countries and African regions $[14,60]$.

\section{Conclusion}

This article described the discussions from the quantity of literatures into four categories so that to capture the discussions on the different results provided from the different researches. The sample of studies into different time frames was taken into consideration to ensure the mixture of ideas and results. The paper categories the discussions into four main sections, first and second sections described by considering the effect of financial sector whether it is positive or negative. Third part describes the effect of financial sector to higher income and lower income countries. The Fourth part explains the transmission channels of financial sector on economic growth. Further subsections to each part are explained within the articles. The results, implications and discussion were presented at each category. It seems that, the effect of financial development on economic growth is subject to selection of time frames selected, sample of countries, list of variables and proxy. However, in most cases it seems that the impact of financial sector is more significant and positive to the developing countries compared to developed countries. Given the recently development of methodologies in terms of econometrics methods and use of proxy such as Financial index, it is important to apply in the future research. This will help to determine the effect of financial sector on economic growth in more advanced way, rather than relies on past proxy and methodologies.

\section{References}

1. Khan SM, Senhadji AS (2000) Financial development and economic growth an overview. IMF Working Paper 00/209, Washington, DC.

2. Khan MA (2008) Financial development and economic growth in Pakistan: evidence based on Autoregressive Distributed Lag (ARDL) approach. South Asia Econ J 9: 375-391.

3. Levine R, Loayza N, Beck T (2000) Financial intermediation and growth: causality and causes. J Monet Econ 46: 31-77.

4. Al-Yousif YK (2002) Financial development and economic growth: Another look at the evidence from developing countries. Rev Financ Econ 11: 131-150.

5. Apergis N, Filippidis I, Economidou C (2007) Financial deepening and economic growth linkages: a panel data analysis. Rev World Econ 143: 179-198.

6. Kar M, Nazlioglu S, Agir H (2010) Financial development and economic growth nexus in the MENA countries: Bootstrap panel granger causality analysis. Econ Model 28: 685-693.

7. Omri A, Daly S, Rault C, Chaibi A (2015) Financial development, environmental quality, trade and economic growth: What causes what in MENA countries. Energy Econ 48: 242-252.

8. Abubakar A, Kassim SHJ, Yusoff MB (2015) Financial Development, Human Capital Accumulation and Economic Growth: Empirical Evidence from the Economic Community of West African States (ECOWAS). Procedia Soc Behav Sci 172: 96-103.

9. Muhammad N, Islam ARM, Marashdeh HA (2015) Financial development and economic growth: An empirical evidence from the GCC countries using static and dynamic panel data. J Econ Financ 40: 773-791.

10. Masoud N, Hardaker G (2012) The impact of financial development on economic growth: Empirical analysis of emerging market countries. Stud Econ Financ 29: 148-173.

11. Beck T, Levine R (2004) Stock markets, banks and growth: panel evidence. J Bank Financ 28: 423-442.
12. Hsueh S, Hu Y, Tu C (2013) Economic growth and financial development in Asian countries: a bootstrap panel Granger causality analysis. Econ model 32: 294-301.

13. Estrada G, Park D, Ramayandi A (2010) Financial development and economic growth in developing Asia. Working paper series No. 233, Asian dev bank econ Manila, Philippines.

14. Pradhan RP, Arvin MB, Bahmani S, Bennett SE (2016) Broadband penetration, financial development, and economic growth nexus: evidence from the Arab league countries. Macroecon Financ Emerg Mark Econ 10: 151-171.

15. Levine R, Zervos S, (1998) Stock markets, banks, and economic growth. Am Econ Rev 88: 537-558.

16. Beck T, Demirgüç-Kunt A, Levine R (2000) A new database on financial development and structure. World Bank Econ Rev 14: 597-605.

17. Assefa TA, Mollick AV (2017) Financial Development and Economic Growth in Africa. J Afr Bus 18: 320-339.

18. Enowbi MB, Mlambo K, Asongu S (2017) Linkages between financial development, financial instability, financial liberalization and economic growth in Africa. Res Int Bus Financ 45: 168-179.

19. Zhang J, Wang L, Wang S (2012) Financial development and economic growth; recent evidence from China. J Comp Econ 40: 393-412.

20. Calderon C, Liu L (2003) The direction of causality between financial development and economic growth. J Dev Econ 72: 321-334.

21. Adu G, Marbuah G, Mensah JT (2013) Financial development and economic growth in Ghana: Does the measure of financial development matter?. Rev Dev Finance 3: 192-203.

22. Uddin GS, Sjo B, and Shahbaz M (2013) The causal nexus between financial development and economic growth in Kenya. Econ Model 35: 701-707.

23. Ang JB, McKibbin WJ (2007) Financial liberalization, financial sector development and growth: evidence from Malaysia. J Dev Econ 84: 215-233.

24. Khan MA, Qayyum A, (2007) Trade liberalization, financial sector reforms and growth. pp: 1-39.

25. Shahbaz M (2009) A reassessment of finance-growth nexus for Pakistan: under the investigation of FMOLS and DOLS techniques. IUP J Appl Econ 1: 65-80.

26. Shahbaz M (2012) Does trade openness affect long run growth? Cointegration, causality and forecast error variance decomposition tests for Pakistan. Econ Model 29: 2325-2339.

27. Kar M, Peker O, Kaplan M (2008) Trade liberalization financial development and economic growth in the long run: the case of Turkey. S E Eur J Econ Bus 3: 25-38.

28. Ghali KH (1999) Financial development and economic growth: The Tunisian experience. Rev of dev econ 3: 310-322.

29. Badeeb RA, Lean HH (2017) Financial development, oil dependence and economic growth: Evidence from the Republic of Yemen. Stud Econ Financ 34: 281-298.

30. Altaee HHA, Al-Jafari MK (2014) Financial Development, Trade Openness and Economic Growth: A Trilateral Analysis of Bahrain. Int J Econ Finance 7: 241.

31. Sbia R, Alrousan S (2016) Does financial development induce economic growth in UAE? The role of capitalization and foreign direct investment: Int J Econ Financ Issues 6: 703-710.

32. Zarrouk H, El Ghak T, Al Haija EA (2017) Financial development, Islamic finance and economic growth: evidence of the UAE. J Islam Acc Bus Res 8: 2-22.

33. Koivu $\mathrm{T}$ (2002) Do efficient banking sectors accelerate growth in transition countries?. BOFIT discussion paper, no.14, pp: 1-28.

34. Ram R (1999) Financial Development and Economic Growth: Additional Evidence, J Dev Stud 35: 164-174.

35. Al-Malkawi HAN, Marashdeh HA, Abdullah N, (2012) Financial development and economic growth in the UAE: Empirical assessment using ARDL approach to co-integration. Int J Econ Finance 4: 105-117. 
Citation: Bakar HO, Sulong Z (2018) The Role of Financial Sector on Economic Growth: Theoretical and Empirical Literature Reviews Analysis. J Glob Econ 6: 309. doi:10.4172/2375-4389.1000309

Page 6 of 6

36. Bolbol A, Fatheldin A, Omran M (2005) Financial development, structure, and economic growth: the case of Egypt, 1974-2002. Res Int Bus Financ 19: 171-94.

37. Jalil A, Ma Y (2008) Financial Development and Economic Growth: Time Series Evidence from Pakistan and Chin. J Econ Coop 29: 29-68.

38. Aziz J, Duenwald C (2002) Growth-Finance Intermediation Nexus in China. International Monetary Fund, IMF Working Paper No. WP/ 02/194, Washington, DC.

39. Demetriades PO, James GA (2011) Finance and growth in Africa: The broken link. Econ Lett 113, 263-265.

40. Demetriades PO, Fielding D (2010) Information, institutions and banking sector development in West Africa. Econ Inq 50: 739-753.

41. Andrianova S, Baltagi B, Demetriades P, Fielding D (2010) The African credit trap. Discussion Papers in Economics 10/18, Department of Economics, University of Leicester.

42. Ayadi R, Arbak E, Ben-Naceur S, De Groen WP (2013) Financial development, bank efficiency and economic growth across the Mediterranean. Economic and Social Development of the Southern and Eastern Mediterranean Countries, pp:219-233.

43. Barajas MA, Chami MR, Yousefi MR (2013) The finance and growth nexus re-examined: Do all countries benefit equally?. IMF Working Paper No. $13 / 130$.

44. Sassi S, Goaied M (2013) Financial development, ICT diffusion and economic growth: lessons from MENA region. Telecomm Policy 37: 252-261.

45. Menyah K, Nazlioglu S, Wolde-Rufael Y (2014) Financial development, trade openness and economic growth in African countries: New insights from a panel causality approach. Econ Model 37: 386-394.

46. Samargandi N, Fidrmuc J, Ghosh S (2015) Is the relationship between financial development and economic growth monotonic? Evidence from a sample of middle income countries. World Dev 68: 66-81.

47. Adeniyi O, Egwaikhide FO, Oyinlola A, Omisakin O (2016) Financial development and economic growth in Nigeria: Evidence from threshold modeling. Econ Anal Policy 47: 11-21.
48. De-Gregorio J, Guidotti P (1995) Financial development and economic growth. World Dev Rev 23: 433-48.

49. Huang HC, Lin SC (2009) Non-linear finance-growth nexus. Econ transit 17: 439-466.

50. Masten AB, Coricelli F, Masten I (2008) Non-linear growth effects of financial development: Does financial integration matter? J Int Money Financ 27: 295-313.

51. Rioja F, Valev N, (2004) Finance and the sources of growth at various stages of economic development. Econ Inq 42: 127-140.

52. Bangake C, Eggoh JC (2011) Further evidence on finance-growth causality: a panel data analysis. Econom Syst 35: 176-188.

53. Herwartz H, Walle YM (2014) Determinants of the link between financial and economic development: evidence from a functional coefficient model. Econ Model 37: 417-427.

54. Owen AL, Temesvary J (2014) Heterogeneity in the growth and finance relationship: How does the impact of bank finance vary by country and type of lending?. Int Rev Econ Financ 31: 275-288.

55. Omran M, Bolbo A (2003) Foreign direct investment, financial development, and economic growth: evidence from Arab countries. Rev Middle East Econ Financ 1: 231-249.

56. Madsen JB, Ang JB (2014) How does financial development transmit to growth?. Review of Economics and Statistics, Just Accepted MS.

57. Hearn B (2014) The political institutional and firm governance determinants of liquidity: evidence from North Africa and the Arab Spring. J Int Financ Market Inst Money 31: 127-158.

58. Asongu SA (2014) Financial development dynamic thresholds of financial globalization: evidence from Africa. J Econ Stud 41: 166-195.

59. Albiman MM, Sulong Z (2017) The linear and non-linear impacts of ICT on economic growth, of disaggregate income groups within SSA region. Telecommunications Policy, 41: 555-572. ISI Thomson Reuter, Q1, IF: 1.562 Elsevier/Science Direct.

60. Asongu SA (2013) How has mobile phone penetration stimulated financial development in Africa?. J Afr Bus 14: 7-18. 